\title{
Palate bone exposure from flexible denture: a case report
}

\author{
Soo-Yoon Jin, Mi-Gyeong Kim, Hee-Jung Kim, Gyeong-Je Lee* \\ Department of Prosthodontics, School of Dentistry, Chosun University, Gwangju, Republic of Korea
}

Recently, flexible denture is widely used with some advantages such as esthetics, flexibility and biocompatibility. However, there is an opposite opinion about stability because of the movement of denture by the material's flexibility. As the denture moves to tissue surface during mastication, it irritates the supporting tissue. It can lead to trauma and rapid resorption of residual ridges if this irritation lasts for a long time. In this case, the patient has used flexible denture with insufficient stability, retention and support for several years and thus continuous irritation of the supporting tissue resulted in palate bone exposure. The patient discomfort and palate bone exposure underwent improvements by the new denture with stability and retention. A careful case selection for flexible denture, regular checkup and proper treatment are necessary to prevent the side effects. (J Dent Rehabil Appl Sci 2017;33(1):1924)

Key words: stability; retention; support; flexible denture; bone exposure

\begin{abstract}
서론
치아의 상실은 심미적 및 생물역학적으로 불리한 후유 증을 동반하게 된다. ${ }^{1}$ 치아의 상실과 함께 잔존치조제에 대한 기능적 자극이 없어지므로 치조제의 부피, 높이 그 리고 너비의 감소가 예상된다. 치조골소실과 연관하여 구강점막의 변화도 동반되는데, 치조골의 부착치은은 덜 각화된 구강 점막으로 바뀌게 되어 외상에 취약해진다. ${ }^{2}$

치아가 상실된 상태에 따라서 여러 가지 치료계획을 고 려할 수 있다. 통상적으로 사용되고 있는 금속-아크릴 국 소의치는 저작 및 심미성을 회복할 수 있는 유용한 치료 방법 중 하나이지만 자연치삭제를 통한 주조금관제작에 따른 비용, 비교적 긴 치료기간과 잦은 내원 횟수 그리고 금속구조물의 손상이나 파절 시 수리가 힘든 단점이 있 다. ${ }^{3,4}$

탄성의치는 심미성, 유연성, 생체적합성 등의 장점이 있 어 최근 많이 사용되고 있다. ${ }^{5}$ 그러나 장기간 사용의 어려

\footnotetext{
*Correspondence to: Gyeong-Je Lee

Assistant Professor, Department of Prosthodontics, School of Dentistry, Chosun University, 303, Pilmun-daero, Dong-gu, Gwangju, 61452, Republic of Korea Tel: +82-62-220-3827, Fax: +82-62-223-7776, E-mail: Ikj1998@chosun.ac.kr Received: January 3, 2017/Last Revision: February 2, 2017/Accepted: February 9, 2017
}

움, 낮은 색조안정성, 낮은 열전도성, 술자에 따른 술식의 민감성, 안정성 결여 등의 문제점이 지적되고 있다. ${ }^{6,7}$ 또 한 재료 자체의 탄성 때문에 저작 시 의치가 조직면으로 침하되어 치은을 자극하고 장기간 사용 시 치조골의 흡 수가 발생할 수도 있다.

본 증례는 안정성이 결여된 탄성의치를 오랜 기간 동안 장착함으로써 구개부의 골노출이 발생한 환자에게 의치 의 안정성이 확보된 새로운 의치를 제작하여 구개골 노 출을 개선시킨 경우이다.

\section{증례보고}

만 81세의 여자 환자가 상악 구개부의 지속적인 통증 과 기존의 상악 의치가 잘 맞지 않아서 불편하다는 주소 로 본원에 내원하였다. 전신질환으로 고혈압과 당뇨가 있었고 지속적으로 약을 복용 중이며 거동이 불편한 상 태였다. 초진 시 구내검사를 시행한 결과 \#11, 21은 잔존

Copyright@ 2017 The Korean Academy of Stomatognathic Function and Occlusion. (c) It is identical to Creative Commons Non-Commercial License. 

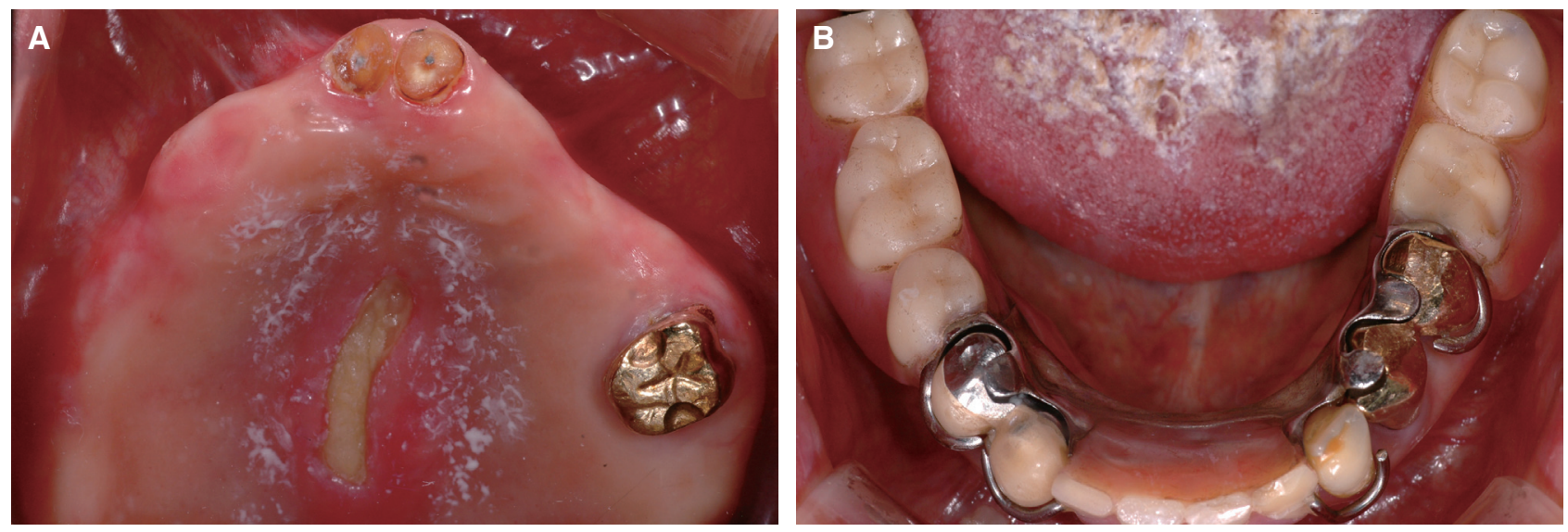

Fig. 1. Intraoral view of $1^{\text {st }}$ visit. (A) Upper arch, (B) Lower arch.

치근 상태, \#26은 써베이드 주조금관으로 동요도가 존 재했으며 이를 지대치로 이용한 탄성의치를 장착 중이었 다. 상악 구개부 중앙에는 길이 약 $3 \mathrm{~cm}$, 너비 약 $0.5 \mathrm{~cm}$ 정도의 골노출 병소가 관찰되었다.

하악에는 \#33, 34, 35와 \#43, 44를 지대치로 이용한 Kennedy Class I modification 1의 양측성 후방연장 국 소의치를 장착하고 있었다(Fig. 1).

기존에 장착하고 있던 의치의 상태를 평가한 결과, 상 악 탄성의치는 \#26 지대치가 편측성으로 유지를 담당하 고 있었다. 잔존치조제와 의치상의 적합도가 불량하여 유지 및 안정성이 상당히 결여되어 있었다(Fig. 2). 환자 는 저작 시마다 상악 탄성의치의 움직임 때문에 발생하 는 구개부와의 마찰로 인해 통증을 호소하였다. 하악 국 소의치의 유지력은 양호했으며 큰 불편감은 없는 상태였 다.

환자는 10 여 년 전에 상악 탄성의치와 하악 국소의치 를 제작하였고 장착 초기에는 큰 불편함이 없었다고 했 다. 그러나 시간이 지나면서 저작 시마다 상악 탄성의치 의 움직임이 문제가 되었고 구개부의 통증이 발생하였 다. 안정성이 결여된 상태의 의치를 오랜 기간 장착하면 서 상악 구개부의 골노출 병소가 점점 커졌지만 인지하 지 못한 상태로 지냈다. 임상적 검사 및 병력청취를 토대 로 환자의 상악 구개부 골노출은 \#26 단독 지대치의 동 요도, 의치상의 적합도 불량으로 인한 유지력 부족 및 안 정성 저하 때문에 발생한 것으로 진단하였다. 가장 불편 감을 호소했었던 상악 탄성의치는 구개부 의치상을 삭제 하여 골노출 부위에 자극이 가해지지 않도록 조정하고 임시로 사용하도록 했다(Fig. 3).

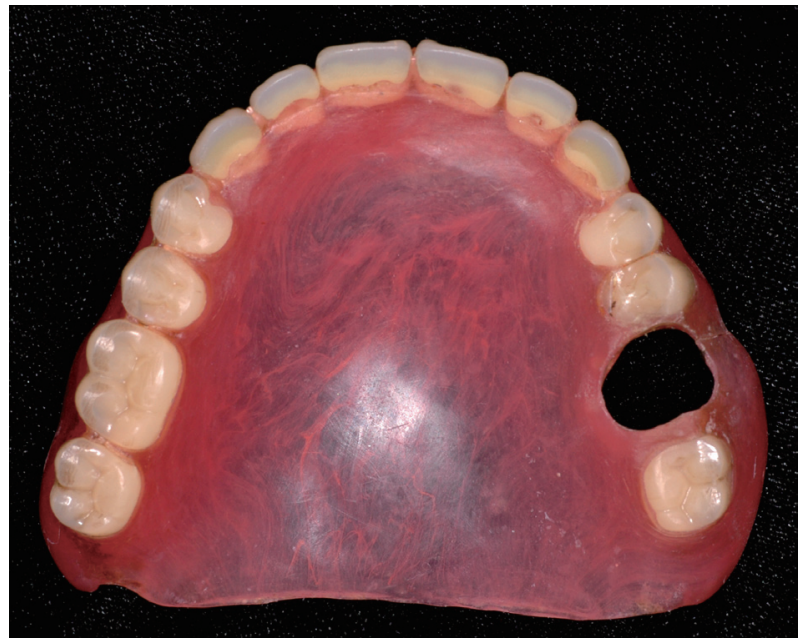

Fig. 2. Flexible denture of $1^{\text {st }}$ visit.

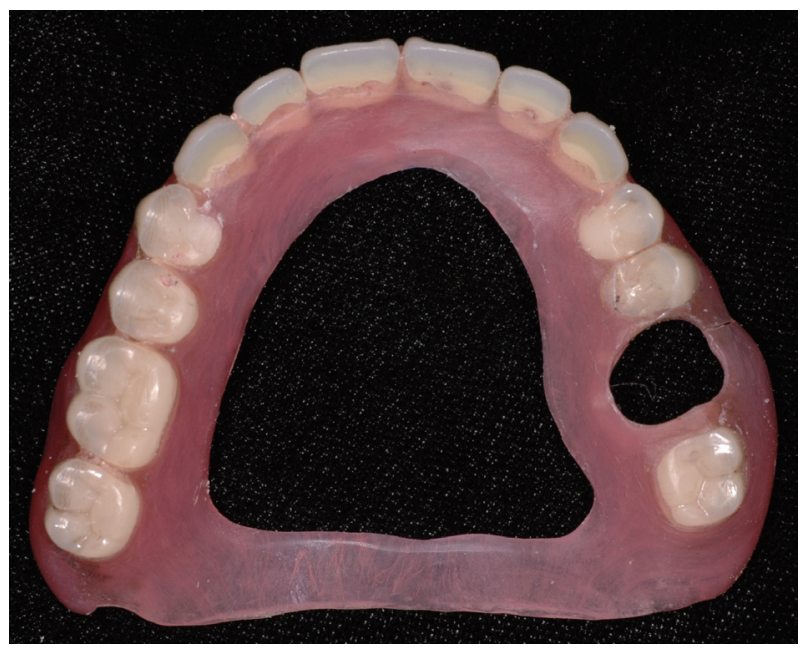

Fig. 3. Trimmed flexible denture. 

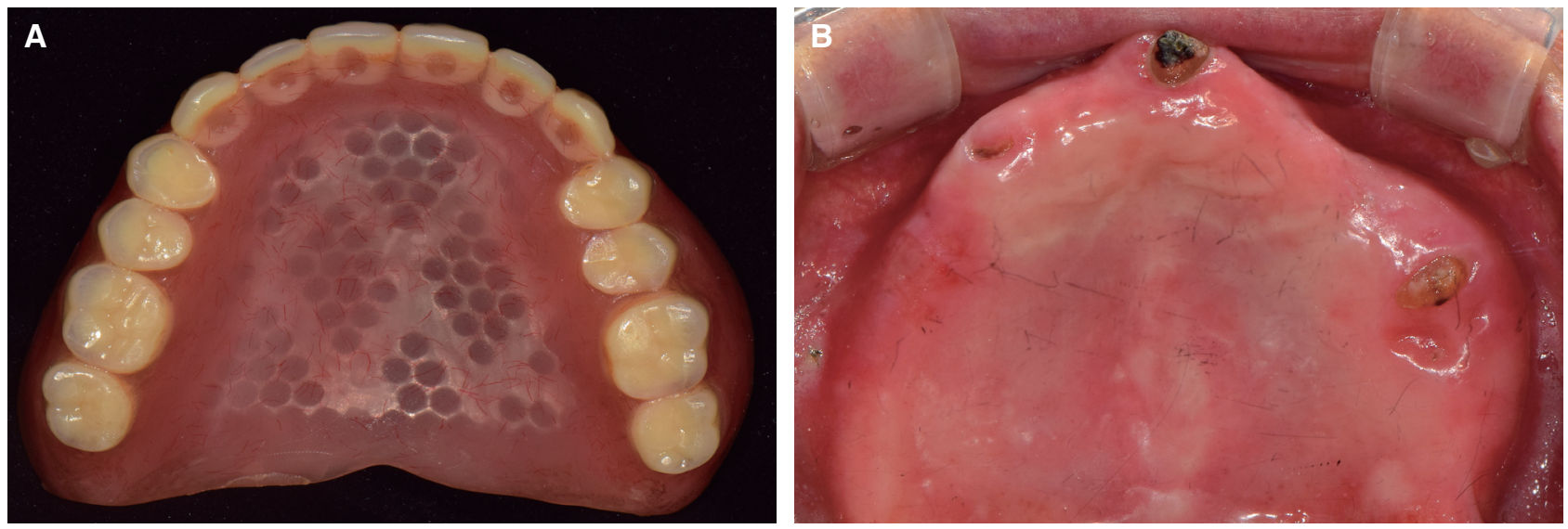

Fig. 4. Conventional complete denture (A), Healed state of bone exposure after wearing new denture (B).

환자가 다시 내원했을 때는 \#26이 치관파절되어 잔존 치근 상태였다. 전신질환으로 고혈압, 당뇨 투병 중이며 거동이 힘들 정도로 환자의 전신건강 상태가 좋지 않았 기 때문에 이를 고려하여 잔존치근은 발거하지 않고 모 두 유지하기로 결정했다. 기존의 하악 국소의치는 큰 불 편감이 없었고 지대치의 우식 및 동요도가 관찰되지 않 았기 때문에 그대로 사용하기로 하였다. 상악은 탄성의 치 대신에 \#11, 21, 26 잔존치근 위로 상악 피개의치를 제작하여 안정성을 확보하고 향후 수리 및 조정이 가능 하도록 하였다.

치료의치 제작을 위한 인상채득을 시행하여 모형을 제 작하였다. 수직고경을 결정하고 중심위를 채득하여 상악 치료의치를 제작하였고 골노출 병소가 치유될 때까지 장 착하였다. 구개부 골노출 부위는 의치 내면조정을 시행 하여 병소부위의 자극을 최소화하였다. 이후 2 개월 동안 경과를 관찰하면서 상악 치료의치의 유지력 및 안정성을 평가하고 병소부위의 내면조정을 시행한 결과 구개부의 통증 및 골노출 병소의 크기가 상당히 감소하였다. 의치 의 양호한 유지력, 안정성을 확보하고 환자가 만족스러 울 정도의 저작 시 편안함을 확인했기 때문에 최종의치 를 제작하기로 결정했다. 상악 총의치는 통상적인 방법 대로 기능인상채득, 수직고경 및 중심위 채득, 중립대에 맞춘 치아배열을 시행하여 제작하였다. 구강 내 장착 후 만족할 만한 유지력과 안정성을 나타냈으며 환자도 심미 적, 기능적으로 모두 만족하였다. 현재까지 경과관찰 중 이며 환자의 골노출 병소는 치유되었고 큰 불편감이 없 는 양호한 결과를 얻었다(Fig. 4).

\section{고찰}

의치를 장착하면 여러 방향으로 하중이 발생하며 잔 존치아와 잔존치조제가 이를 견뎌내야 한다. 지지점막은 각화상피층, 탄성 점막하조직이 있어야 의치의 기능압을 적절히 저항할 수 있다. 잔존치아가 상실되고 잔존치조 제가 흡수되어감에 따라 의치 지지면적은 점점 줄어들게 되고 의치상과 적합도가 불량해지면서 유지, 안정, 지지 가 감소된다. ${ }^{8,9}$ 그리고 호르몬변화와 같은 노화현상이 진 행될수록 구강상피층의 위축이 일어나면서 상피층의 두 께가 얇아지게 된다. 또한 방어기능이 약화되면서 다양 한 자극에 취약해지며 쉽게 외상을 받게 된다., ${ }^{2,10,11}$ 잔존 치아 및 지지점막이 적절한 기능을 하기 위해서는 의치 의 유지 및 안정이 반드시 확보되어야 한다. 유지란 잔존 치조제에서 의치가 삽입철거로 방향으로 탈락하려는 것 에 저항하는 것이며 안정은 의치가 견고하게 수평적 또 는 회전하는 힘에 저항하는 것이다. 본 증례의 탄성의치 에서는 \#26만을 지대치로 하여 의치의 유지를 얻었고 이 로 인해 심각한 유지력 부족과 지대치를 중심으로 한 의 치의 회전이 발생하여 안정성도 심각하게 결여되어 있었 다. 이에 상악 총의치 형태의 치료의치를 제작함으로써 의치의 유지와 안정을 보강하여 상악 구개부의 골노출을 치유시켰으며 다시 한번 의치의 유지와 안정의 중요성을 확인할 수 있었다.

탄성의치는 재료 자체의 투명성과 보이지 않는 클라스 프 설계 등으로 심미성이 우수하며 단량체가 없기 때문에 생체적합성이 좋고 알레르기 반응을 일으키지 않는다. ${ }^{5-7}$ 
그러나 탄성의치의 움직임이 오히려 의치지지조직에 해 로운 힘을 가할 수 있기 때문에 탄성의치를 장기간 사용 하는 것은 일반적으로 추천되지 않는다. 이는 저작 시 의 치가 조직면으로 움직이면서 지지점막을 자극하게 되고, 이런 자극이 장기간 지속될 경우 외상을 일으키며 잔존 치조제의 급속한 흡수를 야기할 수 있기 때문이다. ${ }^{5-7,10,11}$ 또한 탄성의치의 재이장은 같은 재료로만 가능하므로 수 리를 해야 할 때 개상이 추천되고 있어서 금속-아크릴 국 소의치에 비해 향후 유지 및 관리가 어렵다는 단점이 있 다. ${ }^{12}$ 본 증례에서도 장기간에 걸친 탄성의치 사용으로 인 해 골노출이 발생하였고 이는 의치 안정성의 부족이 우 려되는 무치악 부위에서는 탄성의치가 제한적으로 사용 되어야 하며, 불가피하게 사용되더라도 단기간에 걸친 이행의치 정도의 개념으로 사용되어야 함을 반증하는 것 이다.

의치에 교합압이 가해지면 여러 방향으로 움직임이 발 생하는데 특히 후방연장 국소의치의 경우에는 최후방 지 대치를 지점으로 하는 회전운동이 일어나며 의치지지조 직에 해로운 힘이 전달될 수 있다. ${ }^{13}$ 의치를 설계할 때 이 러한 부분을 고려해야 한다. 의치상은 비가동성 점막을 가능하면 넓게 피개해야 하고, 의치의 구성요소는 견고 해야 잔존치조제로 가해지는 교합압과 의치의 움직임을 줄일 수 있다. ${ }^{14,15}$ 움직임이 감소하면 기능하는 동안 안정 된 교합상태를 유지할 수 있고 턱관절이 정상적인 위치 로 유도됨으로써 환자의 불편감을 줄일 수 있다. ${ }^{16}$

본 증례의 환자는 \#26을 단독 지대치로 사용하는 상 악 탄성의치를 오랜 기간 사용하고 있었다. 의치를 제작 한 이후에는 정기적인 검진을 받지 않았고 의치의 적합 도가 점차 낮아진 결과로 저작 시마다 우측 의치상이 좌 측보다 더 침하되면서 의치의 움직임이 발생하고 있었다. 잔존치조제의 흡수가 진행되면서 의치의 적합도가 감소 하면 안정성을 확보하기 위해 적절한 시기에 의치 조직 면의 재이장 또는 재제작을 시행해야 하며, ${ }^{17}$ 정기적으로 치과를 방문하여 문제점이 발생하기 전에 예방하는 것이 중요하다. 하지만 본 환자는 기존 탄성의치를 계속 사용 하면서 안정성 및 유지력이 불량하게 되었다. 이와 같은 이유로 구개부에 지속적인 자극이 가해졌으며 골노출 병 소가 발생한 것으로 보인다. 총의치 형태의 치료의치를 제작하고 장착한 결과 안정, 유지를 확보할 수 있었다. 안정성, 유지력이 확보된 새로운 의치는 환자의 불편감 을 크게 개선하였고 골노출 병소의 치유도 양호하였다.

\section{결론}

탄성의치의 매력적인 장점들이 있지만 재료 자체의 유 연성에 의한 의치의 움직임 때문에 안정성에 대한 문제가 제기되고 있다. 본 증례는 안정 및 유지가 감소한 탄성의 치를 장기간 사용하면서 구개부의 심한 골노출까지 발생 했던 드문 경우였다. 진단 및 치료계획단계에서 탄성의치 를 사용할 수 있는 증례를 신중하게 선택해야 할 것이다. 또한 의치의 기본 요건인 안정, 유지, 지지를 평가하여 양 호하지 못한 경우에는 적절한 처치를 시행하여 부작용을 예방할 수 있어야 한다.

\section{ORCID}

Soo-Yoon Jin http://ordid.org/0000-0002-4910-0286

Mi-Gyeong Kim http://ordid.org/0000-0001-9636-0761

Hee-Jung Kim http://ordid.org/0000-0002-2015-1530

Gyeong-Je Lee http://ordid.org/0000-0002-3545-2280

\section{References}

1. Weintraub JA, Burt BA. Oral health status in the United States: tooth loss and edentulism. J Dent Educ 1985;49:368-78.

2. Tomlin HR, Wilson HJ, Osborne J. The thickness and hardness of soft tissues. A preliminary clinical survey. Br Dent J 1968;124:223-6.

3. Cowan RD, Gilbert JA, Elledge DA, McGlynn FD. Patient use of removable partial dentures: two- and four-year telephone interviews. J Prosthet Dent 1991;65:668-70.

4. Budtz-Jørgensen E, Bochet G, Grundman M, Borgis $\mathrm{S}$. Aesthetic considerations for the treatment of partially edentulous patients with removable dentures. Pract Periodontics Aesthet Dent 2000;12:76572.

5. Singh JP, Dhiman RK, Bedi RP, Girish SH. Flexible denture base material: a viable alternative to conventional acrylic denture base material. Contemp Clin Dent 2011;2:313-7.

6. Shamnur SN, Jagadeesh KN, Kalavathi SD, Kashinath KR. "Flexible dentures" - an alternate for rigid dentures? J Dent Sci Res 2005;1:74-9. 
7. Thakral GK, Aeran H, Yadav B, Thakral R. Flexible partial dentures - a hope for the challenged mouth. PJSR 2012;5:55-9.

8. Atwood DA. Bone loss of edentulous alveolar ridges. J Periodontol 1979;50:11-21.

9. Atwood DA, Coy WA. Clinical, cephalometric, and densitometric study of reduction of residual ridges. J Prosthet Dent 1971;26:280-95.

10. Coelho CM, Sousa YT, Daré AM. Denture related oral mucosal lesions in a Brazilian school of dentistry. J Oral Rehabil 2004;31:135-9.

11. Sato T, Hara T, Mori S, Shirai H, Minagi S. Threshold for bone resorption induced by continuous and intermittent pressure in the rat hard palate. J Dent Res 1998;77: 387-92.

12. Park CW, Hwang YP, Kay KS. Prosthetic restoration of partially edentulous patients using the Valplast flexible partial denture system. Oral Biol Res 2006;30:55-73.

13. Glantz PO, Stafford GD. The effect of some com- ponents on the rigidity of mandibular bilateral free end saddle dentures. J Oral Rehabil 1980;7:423-33.

14. Kitamura S, Suzuki Y. In vivo assessment of occlusal stress distribution in distal extension removable partial dentures: connecting rigidity and denturesupporting area affecting the stress distribution. Tsurumi Univ Dent J 2006;32:117-24.

15. Igarashi Y, Kawata M, Asami M. The connecting rigidity between abutment teeth and retainers in RPDs. Part 1: the connecting rigidity in various clasp retainers. J Jpn Prosthodont Soc 1990;34: 1162-9.

16. Igarashi Y, Kawata M, Shiba A. Restoration of the "supporting zone" of the mandible in partial dentate mouth (Part 5). Supporting ability of free-end saddle RPD's. Showa Shigakkai Zasshi 1987;7:195206.

17. Qudah S, Harrison A, Huggett R. Soft lining materials in prosthetic dentistry: a review. Int J Prosthodont 1990;3:477-83. 


\section{탄성의치에 의한 구개부 골노출 증례}

\section{진수윤, 김미경, 김희중, 이경제*}

조선대학교 치과대학 치과보철학교실

탄성의치는 심미성, 유연성, 생체적합성 등의 장점이 있어서 최근 많이 사용되고 있다. 그러나 재료 자체의 유연성에 의한 의치의 운동 때문에 안정성에 대한 문제가 제기되고 있다. 저작 시 의치가 조직면으로 움직이면서 지지조직을 자극하게 되 고, 이런 자극이 장기간 지속될 경우 외상과 잔존치조제의 급속한 흡수를 야기할 수 있기 때문이다. 본 증례에서는 안정, 유지 및 지지가 부족한 탄성의치를 장기간 사용하면서 지지점막의 지속적인 자극으로 인한 구개골 노출이 발생하였다. 안 정성 및 유지력이 확보된 새로운 의치를 제작하여 환자의 불편감이 감소하였고 구개골 노출이 치유되었다. 탄성의치를 사 용할 수 있는 증례를 신중하게 선택해야 하며 정기검진 및 적절한 처치를 시행하여 부작용을 예방할 수 있어야 한다.

(구강회복응용과학지 2017;33(1):19-24)

주요어: 안정; 유지; 지지; 탄성의치; 골노출 